\title{
Tour guide training for hospitable, nature-based tour experiences
}

\section{Brooke A. Porter and Michael Lück}

Dr Brooke Porter is a postdoctoral research fellow in the School of Hospitality and Tourism at AUT. Her research explores human interactions with aquatic spaces. She also serves as scientific adviser to The Coral Triangle Conservancy, in the Philippines and teaches environmental science at the Umbra Institute in Perugia, Italy.

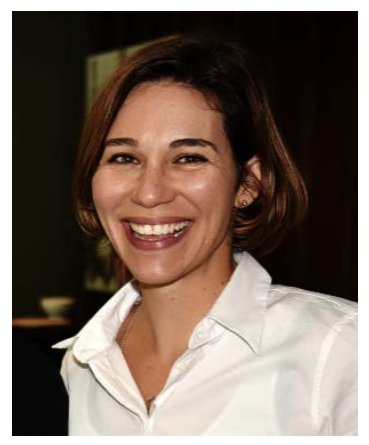

Dr Michael Lück is a professor in the School of Hospitality and Tourism, associate director for the coastal and marine tourism research programme at the New Zealand Tourism Research Institute at AUT, NZ, and founding co-chair of the International Coastal \& Marine Tourism Society (ICMTS). His research interests include marine wildlife tours, the cruise industry, ecotourism, the
The term 'hospitality' has long been linked to accommodation providers and eateries, but the wider range of hospitality, and hospitable experiences, has received little attention from academics and practitioners alike. Although tourism and hospitality are undeniably linked, Lynch [1] notes that "in tourism, there is a curious neglect of welcome given its associations with the idea of universal hospitality" (p. 174). To this end, we argue that hospitality goes well beyond food and accommodation alone, and includes any host-tourist interactions, such as those between guides and tour participants.

Participants aboard nature-based marine tours are expecting to learn [2]. However, the guide's ability to 'connect' with their audience and provide quality learning experiences is not part of an industry standard. As a result, the expertise and personality of guides varies, as do their duties and their levels of training. Learning is a critical component of nature-based tours, thus placing significant responsibility on the guide in the creation of a hospitable experience. For naturebased wildlife tour operators in New Zealand (and globally), in many cases guide training efforts are a choice left up to the operators. While individual operators' needs may vary, previous hospitality research suggests that beyond fulfilling visitor expectations, appropriate training not only benefits guests, but also increases workplace satisfaction [3]. This paper discusses the need for guide training in increasing the hospitable experience aboard nature-based wildlife tours.

Through data captured in self-administered visitor surveys, we explored over 400 participants' perceptions of guide abilities related to a hospitable, or pleasant, experience [4]. Tour participants on swim-with wild dolphins tours were asked to rate the importance of items related to their on-tour experience. All items were rated on a five-point scale. Over $93 \%$ of the respondents thought that having a knowledgeable and helpful boat crew was important, and more specifically over $90 \%$ felt having a knowledgeable guide on board was important. Likewise, the majority of participants identified the importance of learning about various subjects, such as the natural environment $(69 \%)$ and threats to marine life $(66 \%)$ - a responsibility that falls to the guides and crew. Being able to understand the safety rules was of near comparable importance to the learning experience desires $(86 \%)$, as was the cleanliness of the vessel (85\%). Our findings demonstrated that in order to create a hospitable experience, marine tour guides must fulfil dual roles as crew and naturalists. The high values placed on educational and safety information emphasise the critical role of knowledgeable guides/crew aboard nature-based tours. While it is apparent that many guides 
impacts of tourism, and aviation.

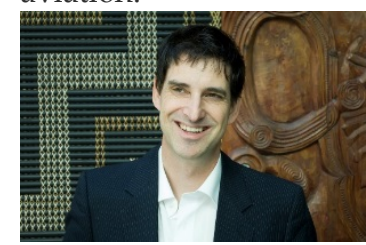

take pride in their work, with many furthering their knowledge during their personal time, the findings from our study highlight the importance of the guide's role in the overall visitor experience.

While some tour components, such as the safety messages, are matters of legal compliance (and clearly were of high importance to participants as well), other components such as fulfilling the educational desires of visitors should be carefully considered by operators. Our findings show that visitors place a high importance on tour components that are directly related to a guide's performance, personality and abilities. Options for operators include requiring a minimum qualification for guides (e.g., a bachelor's degree in a related field) and/or an investment in continuing and specialised education. In conclusion, guide training on the natural environment and conservation as well as vessel/marine safety is essential. More specifically, this means that operators stand to benefit from guide training that reaches beyond the factual information and includes interpretation techniques. This may seem like a large investment for operators; however, the findings from this research indicate that visitor satisfaction is dependent upon this investment. The role of guides aboard naturebased wildlife tours is central to the overall hospitable experience.

The original research on which this article was based can be accessed here: https://doi.org/10.1080/14724049.2017.1353609

\section{Corresponding author}

Brooke Porter can be contacted at: bporter@aut.ac.nz

\section{References}

(1) Lynch, P. Mundane Welcome: Hospitality as Life Politics. Annals of Tourism Research 2017, 64, 174-184. http://dx.doi.org/10.1016/j.annals.2017.04.001

(2) Lück, M. Education on Marine Mammal Tours - but What Do Tourists Want to Learn? Ocean \& Coastal Management 2015, 103, 25-33.

http://dx.doi.org/10.1016/j.ocecoaman.2014.11.002

(3) Poulston, J. Hospitality Workplace Problems and Poor Training: A Close Relationship. International Journal of Contemporary Hospitality Management 2008, 20(4), 412-427.

(4) Lück, M.; Porter, B.A. Experiences on Swim-With-Dolphins Tours: An ImportancePerformance Analysis of Dolphin Tour Participants in Kaikoura, New Zealand. Journal of Ecotourism 2017, 1-17. https://doi.org/10.1080/14724049.2017.1353609 